\title{
Analisis Yuridis terhadap Tindak Pidana Pembunuhan Berencana Dan Penganiayaan terhadap Anak yang Mengakibatkan Luka Berat (Studi Putusan No. 36/Pid.B/2016/PN.MLL)
}

\author{
Pajriniah Dwi Napanti ${ }^{1)}$, Raden Yulia Kartika ${ }^{2)}$ \\ ${ }^{12}$ Fakultas Hukum, Universitas Singaperbangsa Karawang \\ Jl. HS. Ronggo Waluyo, Puseurjaya, Kec. Telukjambe Timur, Kabupaten Karawang, Jawa Barat 41361 \\ correspondence email: pajriniahdwi24@gmail.com, rdiyulk@gmail.com
}

\begin{abstract}
Abstrak. Tinjauan ini mengkaji penggunaan hukum terhadap kesalahan pembunuhan berencanadan pertimbangan hakim dalam menangani kesalahan pembunuhan berencana dan penyalahgunaan anak yang mengakibatkan luka yang nyata. Eksplorasi ini merupakan pemeriksaan yuridis yang mengatur. Metodologi yuridis regularisasi adalah metodologi yang memeriksa spekulasi, gagasan, standar hukum dan pedoman hukum. Strategi pengumpulan bahan-bahan hukum yang esensial dan bahan-bahan yang sah opsional menggunakan strategi pengumpulan bahan-bahan yang halal dengan studi menulis. Hasil penelitian menunjukkan bahwa pendayagunaan hukum terhadap perbuatan melawan hukum pembunuhan berencana dan penganiayaan terhadap anak yang menimbulkan luka yang nyata mengabaikan Pasal 340 KUHP dan Pasal 80 Ayat (2) Undang-Undang Nomor 23 Tahun 2002 tentang Perlindungan Anak, menunjukkan bahwa responden melakukan kesalahan pembunuhan berencana. Terlebih lagi, penyalahgunaan anak membawa luka yang nyata. Pemikiran otoritas yang ditunjuk dalam menangani kesalahan ini, memaksa penahanan keberadaan sehari-hari. Termohon dituding telah melakukan tindak pidana pembunuhan berencana yang mengakibatkan meninggalnya korban Christina Tandioga dan penyalahgunaan anak yang mengakibatkan luka serius pada Sestika Santika. Misalnya, dakwaan pokok Jaksa Penuntut Umum Pasal 340 KUHP dan dakwaan pokok kedua Jaksa Penuntut Umum, Pasal 80 Ayat (2) Undang-Undang Nomor 23 Tahun 2002.
\end{abstract}

Kata Kunci: Pembunuhan Berencana, Penganiayaan, Putusan

\begin{abstract}
This review inspects the use of the law to the wrongdoing of planned homicide and judges' contemplations in taking care of the wrongdoing of planned homicide and youngster misuse that outcomes in genuine wounds. This exploration is a regulating juridical examination. The regularizing juridical methodology is a methodology that inspects speculations, ideas, lawful standards and legal guidelines. The strategy of gathering essential lawful materials and optional legitimate materials utilizes the strategies of gathering lawful materials with writing study. The outcomes showed that the utilization of the law against the wrongdoing of planned homicide and abuse of kids bringing about genuine wounds disregards Article 340 of the Criminal Code and Article 80 Paragraph (2) of Law Number 23 of 2002 concerning Child Protection, demonstrating that the respondent perpetrated the wrongdoing of planned homicide. What's more, youngster misuse bringing about genuine wounds. The appointed authority's thought in dealing with this wrongdoing, forces a daily existence detainment. The respondent was accused of having perpetrated a wrongdoing of planned homicide which brought about the passing of casualty Christina Tandioga and youngster misuse which brought about genuine injury to Sestika Santika. For instance, the essential incrimination of the Public Prosecutor, Article 340 of the Criminal Code and the second prime incrimination of the Public Prosecutor, Article 80 Paragraph (2) of Law Number 23 Year 2002.
\end{abstract}

Keywords: Planned Murder, Persecution, Verdict

\section{PENDAHULUAN}

Perilaku yang tidak sesuai standar akan menimbulkan tanggapan sebaliknyadari orang lain. Tingkah laku yang menyimpang dari norma biasanya akan menimbulkan persoalan lain di bidang hukum dan kerusakan masyarakat. ${ }^{1}$ Undang-undang ini dibuat sepenuhnya bertujuan untuk mengarahkan kehidupan di mata masyarakat untuk membuat permintaan, kedamaian, keadilan dan kesuksesan.

Isu sah yang sering muncul di arena publik adalah isu yang selalu diidentikkan dengan kesetaraan, yang merupakan isu lama yang tetap menarik dan nyata. Individu dalam melakukan rutinitas rutin mereka benar-benar membutuhkan hukum dan keadilan. Ada isu-isu yang terus-menerus terkait antar jaringan, khususnya kesalahan dan pelanggaran. Perbuatan salah adalah masalah yang dapat melukai diri sendiri dan merugikan orang lain. Perbuatan salah dapat secara langsung diidentikkan dengan hukum, khususnya hukum pidana, dimana hukum pidana merupakan salah satu kerangka yang dibutuhkan oleh masyarakat sesuai dengan kemajuan masyarakat itu sendiri.

Hukum pidana adalah suatu norma yang dibuat dan dilaksanakan oleh suatubangsa, untuk mengetahui kegiatan mana yang tidak boleh dilakukan dan kegiatan yang boleh dilakukan, jika perbuatan yang tidak diperbolehkan itu dilakukan olehdaerah, maka daerah setempat akibatnya akan langsung diidentikkan dengan penjahatnya. Larangan

${ }^{1}$ Bambang Waluyo, 2000, Pidana dan Pemidanaan, Sinar grafika, Jakarta, hlm 3. 
dan komitmen tertentu yang harus dipatuhi oleh setiap wilayah lokal, Negara harus diingat untuk undang-undang dan undang-undangtidak resmi, baik di tingkat fokal maupun teritorial. ${ }^{2}$

Hukum pidana penting bagi hukum umum yang berlaku di suatu negara, yang memberikan dasar dan aturan untuk:

1. Cari tahu kegiatan mana yang tidak boleh dilakukan dan mana yang dilarang, ditambah dengan bahaya atau otorisasi sebagai kesalahan khususuntuk setiap individu yang mengabaikan larangan tersebut;

2. Memutuskan kapan dan dalam hal apa orang-orang yang menyalahgunakan larangan itu dapat dipaksakan atau dihukum untuk melakukan tindakpidana sebagaimana diungkapkan;

3. Memutuskan bagaimana beban disiplin dapat dilakukan jika ada individu yang terkait dengan penyalahgunaan larangan tersebut. ${ }^{3}$

Demonstrasi kriminal adalah perbuatan manusia yang dirinci dalam undang-undang, ilegal, yang berhak untuk ditolak dan dilakukan secara salah. Orang-orang yang melakukan demonstrasi kriminal harus dianggap bertanggung jawab atas kegiatan mereka dengan penahanan atau penindasan sesuai dengan kesalahan langkah yang mereka buat. Seorang individu melakukan kesalahan saat melakukan demonstrasi dilihat dari sudut pandang masyarakat yang menunjukkan cara pandang yang mengatur atas kesalahan yang dilakukan. ${ }^{4}$

Pembunuhan adalah pembunuhan yang disengaja atas nyawa orang lain, untuk menghilangkan keberadaan orang lain, pelakunya harus menyelesaikan sesuatu atau suatu rangkaian kegiatan yang mengakibatkan meninggalnya orang lain dengan catatan pelakunya harus menunjukkan akibat sebagai kematian. dari individu lainnya. ${ }^{5}$ Pembunuhan terencana atau pembunuhan berencana adalah pembunuhan yang dilakukan oleh pelakunya terlebih dahulu sebelum mengajukandemonstrasi pembunuhan, dengan tujuan agar kegiatan pembunuhan tersebutberjalan sesuai dengan yang diharapkan.

Pembunuhan berencana adalah perbuatan salah yang termuat dalam Buku IIKUHP, yang diatur dalam Pasal 340 KUHP yang berbunyi "Setiap orang yang dengan sengaja dan dengan rencana terlebih dahulu mengakhiri keberadaan orang lain, dirusak dengan pembunuhan berencana, dengan hukuman mati atau penahanan seumur hidup, atau sekali lagi untuk jangka waktu tertentu, paling lamadua puluh tahun". Variabel yang paling mempengaruhi seseorang untuk mengajukan pembunuhan berencana adalah: perasaan pembalasan karena tersinggung, korban membuat gerakan yang melukai pelakunya, keinginan sosial, posisi dan masalah pemerintahan. Pembunuhan terdiri dari beberapa jenis, diantaranya : 6

1. Pembunuhan biasa (Doodslag)

Pembunuhan biasa ini sebagaimana diatur dalam Pasal 338 KUHP, yang pada intinya berbunyi "Setiap orang yang dengan sengaja mengakhiri keberadaan orang lain dipidana mati dengan pidana kurungan paling lama lima belas tahun".

2. Pembunuhan yang direncanakan terlebih dahulu (Moord)

Yang dimaksud dengan diatur sebelumnya adalah adanya penundaan antara jampelaksanaan demonstrasi dan kapan timbul keinginan untuk melakukan kegiatan tersebut.

Antara saat timbul keinginan untuk melakukan perbuatan dan ketika demonstrasi selesai, pelaku mempunyai kesempatan yang cukup untuk merenungkan dan memikirkan bagaimana cara melaksanakan perbuatan itu danbahkan memutuskan kesempatan untuk melakukan perbuatan itu, bahkan mungkin memutuskan aparatur untuk melakukan perbuatan itu. dimanfaatkan,tempat bermain akta, dll.

Bukan hanya pembunuhan berencana, di mata publik juga ada pelanggaran yang terkait dengan tubuh manusia, khususnya pelecehan. Pembunuhan berencana dan siksaan adalah tindakan yang tidak dilandasi moral dan etika sehingga kesalahan yang dilakukan oleh satu pelaku dapat merugikan orang lain.

Menurut yurisprudensi pengadilan yang dinamakan penganiayaan adalah $:^{7}$

1. Sengaja menimbulkan sentimen yang buruk (mendekam)

2. Menyebabkan siksaan

3. Menyebabkan luka

${ }^{2}$ P. A. F. Lamintan, Theo Lamintang, Kejahatan Terhadap Nyawa, Tubuh dan Kesehatan, Sinar Grafika, Jakarta, 2012, hlm 1 .

${ }^{3}$ Moeljanto, Asas-Asas Hukum Pidana, Rineka Cipta, Jakarta, Cet.8, Edisi Revisi, 2012, hlm 1.

${ }^{4}$ Andi Hamzah, Bunga Rampai Hukum Pidana dan Acara Pidana, Ghalia Indonesia, Jakarta, 2001, hlm 22.

${ }^{5}$ Wahyu Adnan, Kejahatan Terhadap Tubuh dan Nyawa, Gunung Aksara, Bandung, 2007, hlm 45.

${ }^{6}$ R. Soesilo, Kitab Undang-Undang Hukum Pidana, Politeia, Bandung, 1996, hlm 240.

${ }^{7}$ R. Soesilo, KUHP Serta Komentar-Komentarnya Lengkap Pasal Demi Pasal, Politeia, Bogor, 1995, hlm 245. 
Menurut Purwodarminto, pelecehan adalah perlakuan yang mementingkan diri sendiri sehubungan dengan menyiksa atau menganiaya orang lain. ${ }^{8}$ Banyaknya kasus penyalahgunaan yang terjadi secara lokal merupakan jenis perilaku lokal yang tidak terkendali, karena kurangnya informasi moral dan etika serta iklim sosial yang buruk, misalnya penganiayaan anak oleh wali. Hal yang berbeda adalah tidak adanya informasi tentang bagaimana menjadi orang tua, tidakadanya ketersediaan untuk menjadi orang tua dan tidak memahami keinginan waliuntuk anak-anaknya.

Anak adalah anugrah yang diberikan Tuhan, sehingga realitas mereka adalah sesuatu yang harus dikembangkan oleh para wali, sehingga mereka menjadipribadi yang berharga bagi negara dan negara. Anak-anak memainkan peran penting untuk melanjutkan negara ini, oleh karena itu anak-anak berhak untuk dilindungi dari demonstrasi kebiadaban dan pemisahan. Keistimewaan anak-anakyang harus dipenuhi adalah:

1. Hak Untuk Bermain

2. Hak atas Pendidikan

3. Hak atas Perlindungan

4. Hak Rekreasi

5. Hak atas Pangan

6. Hak atas Akses Kesehatan

7. Hak untuk Memperoleh Nama atau Identitas

8. Hak Status Nasional

9. Hak untuk Berpartisipasi dalam Pembangunan

10.Hak atas Kesetaraan

Penindasan adalah demonstrasi yang bertentangan dengan standar hukum sehingga dihalangi oleh hukum. Pasal 351 KUHP direncanakan sebagai berikut:

1. Penindasan diancam dengan pidana kurungan paling berat dua tahun delapanbulan atau denda paling banyak 4.000.500 rupiah

2. Dalam hal demonstrasi tersebut menimbulkan kerugian yang nyata, orangyang bersalah diancam dengan hukuman penjara paling lama lima tahun.

3. Dalam hal hal itu menyebabkan kematian, itu adalah hukuman paling berattujuh tahun

4. Penindasan setara dengan sengaja merusak kesejahteraan

5. Berusaha untuk melakukan kesalahan ini tidak bersalah.

Anak adalah seseorang yang sangat membutuhkan kasih sayang dan perhatian dari kedua wali dan iklim keluarga. Bagaimanapun, tanpa kita memahaminya, wali adalah elemen utama untuk menyakiti anak-anak mereka dengan cara yang berbeda. Anak-anak yang harus dibimbing sambil merenung danmemberikan bimbingan yang baik karena anak adalah seseorang yang memiliki minat yang tinggi, sebenarnya dianggap oleh para wali sebagai beban.

Berdasarkan gambaran latar belakang permasalahan tersebut, maka pencipta akan melihat permasalahan utama, bagaimana penerapan hukum terhadap kesalahan pembunuhan berencana dan penyalahgunaan anak yang menimbulkan luka yang nyata, maka pada saat itu, yang kedua bagaimana pemikiran pejabat yang ditunjuk dalam menangani kesalahan pembunuhan berencana dan penyalahgunaan anak yang menyebabkan cedera serius.

\section{METODE}

Strategi pemeriksaan adalah metode bertindak sesuai dengan pengaturan keputusan yang direncanakan untuk berfungsi secara normal dan terkoordinasi untuk mencapai hasil yang ideal. Pemeriksaan adalah upaya menemukan realitas sesuai dengan strategi sasaran yang masuk akal untuk menemukan hubungan realitas dan menghasilkan rekomendasi atau hukum.

Untuk mempermudah dalam mengkoordinir strategi eksplorasi yangdigunakan dalam pendahuluan buku harian ini, maka disusun pendahuluan beberapa hal terkait, seperti di bawah ini:

1. Pendekatan Penelitian

Cara menyikapi masalah dalam tinjauan ini menggunakan strategi yuridis regularizing, yaitu suatu metodologi yang dimulai dari pengaturan undang- undang dan hambatan-hambatannya. Metodologi yuridis standarisasi ini juga merupakan metodologi yang bergantung pada standar atau pedoman hukum yang membatasi dan memiliki hasil yang sah dan jelas serta menggunakan strategi penelitian lapangan yang mencakup anggapan dan perspektif di daerah setempat.

2. Spesifikasi Penelitian

Ide pengujian digunakan dalam spellbinding ilmiah, yang merupakan tinjauan dengan menekankan cara menggambar, menggambarkan dan memecah masalah tergantung pada Studi Keputusan Nomor

${ }^{8}$ Poerdarminto, Kamus Umum Bahasa Indonesia. Balai Pustaka, Jakarta, 2003, hlm 48. 
36/Pid.B/2016/PN.MLL

3. Jenis dan Sumber Data sekunder.

Jenis data yang akan digunakan dalam penelitian ini terdiri atas dua kategori, yaitu data primer dan data

a. Data Primer

Itulah informasi yang langsung digunakan dalam penelitian di lapangan.

b. Data Sekunder

Khususnya informasi yang diperoleh dari bahan pustaka, file dan catatan yang diidentifikasi dengan objek pemeriksaan. Dalam pemeriksaan yang sah, keterangan pilihan memuat bahan-bahan hukum yang esensial, yang meliputi Kitab Undang-undang Hukum Pidana (KUHP), Kitab Undang-Undang Hukum Acara Pidana (KUHAP) dan Undang-Undang Nomor 4 tentang Kekuasaan Kehakiman. Yang kedua adalah bahan hukum pilihan, yaitu bahan yang memperjelas bahan-bahan penting yang halal yang terdiri dari laporan eksplorasi, pengandaian yang memenuhi syarat seperti buku, makalah, buku harian, dll. Terlebih lagi, yang terakhir adalah bahan hukum tersier. Bahan sah tersier adalah bahan hukum yang berkonsentrasi pada bahan hukum esensial dan bahan hukum tambahan. Lebih tepatnya Kamus Hukum, Kamus Bahasa Indonesia dan Kamus Bahasa Asing.

4. Teknik Pengumpulan Data

Strategi pengumpulan informasi yang digunakan adalah sebagai berikut: Studi Literatur. Penulis menggunakan buku atau tulisan sebagai semacam perspektif dan latar belakang yang dapat digunakan sebagai bahan untuk komposisi ini.

5. Teknik Analisis Data

Informasi yang diperoleh melalui pemeriksaan tambahan disusun dan disusun secara sengaja, bijaksana dan yuridis untuk mendapatkan gambaran tentang objek eksplorasi. Selain itu, penggambaran objek pemeriksaan secara keseluruhan dibedah dengan menggunakan strategi subyektif yang memukau, yaitu penyelidikan informasi spesifik yang diharapkan dapat menggambarkan kondisi, keadaan, dan keajaiban dari konsekuensi berbagai informasi dari responden yang memiliki atribut dan beban subyektif yang kemudian digunakanuntuk disimpulakn.

\section{Hasil DAN PEMBAHASAN \\ Penerpaan Hukum Terhadap Tindak Pidana Pembunuhan Berencana danPenganiayaan Terhadap Anak Yang Mengakibatkan Luka Berat dalam Studi Putusan No. 36/Pid.B/2016/PN. MLL}

Penulis akan melakukan analisis yuridis yaitu dengan menilai fakta-fakta perbuatan dan petunjuk dalam pemeriksaan persidangan yang diuraikan dalamanalisis fakta kemudian diterapkan ke dalam pembuktian unsur-unsur atau kualifikasi dari perbuatan tindak pidana yang dilakukan dengan memperhatikan dakwaan dari Jaksa Penuntut Umum, maka secara yuridis terlihat bahwa JaksaPenuntut Umum mendakwakan terdakwa Alwi Rongkeng Alias Awi sebagai pelaku tindak pidana pembunuhan berencana dan penganiayaan terhadap anakyang mengakibatkan luka berat. Adapun unsur atau kualifikasi, sebagai berikut:

Perbuatan terdakwa diatur dan diancam pidana sebagaimana Pasal 340 KUHP yang unsur-unsurnya sebagai berikut:

1. Barang Siapa

Komponen barang siapa untuk mengetahui siapa pelaku suatu tindak pidana berjalan sebagai subjek yang sah yang telah melakukan kesalahan dan dapat sadar tergantung pada keadaan dan kemampuan intelektualnya (geestelijke vemogens) yang dalam sila hukum pidana diuraikan sebagai dalam keadaan sadar. Bahwa dari kenyataan-kenyataan yang muncul pada pemeriksaan pendahuluan, lebih spesifik keterangan saksi-saksi yang dibandingkan satu sama lain, diidentikkan dengan keterangan-keterangan dari pihak yang berperkara, bahwa sebenarnya yang terjadi adalah Termohon Alwi Rongkeng Alias Awi dengan tokoh tersebut. dalam keadaan sehat jasmani dan rohani yang dapat diterima, sehingga ia dapat diwakili oleh hukum, olehnya Unsur Barang yang telah dipenuhinya.

2. Dengan Sengaja dan Dengan Rencana Terlebih Dahulu

Komponen sengaja dan mendahului waktu adalah suatu keadaan atau keadaan pelaku yang selama melakukan aktivitasnya membutuhkan waktu atau jeda untuk awalnya mengambil sikap tenang dalam menetapkan pilihan untuk memusnahkan jiwa dan pelaksanaannya adalah suatu solidaritas. Selain itu, situasi waktu atau jeda dipandang sebagai jangka waktu yang diharapkan untuk merenungkan pelaksanaannya dan lebih jauh lagi merupakan jangka waktu untuk memberikan kesempatan untuk membatalkan pelaksanaannya. Dari kenyataan sementara saat ini, fakta- fakta menegaskan bahwa peristiwa pembakaran itu terjadi sekitar 6 (enam) waktu yang lalu, tepatnya pada hari Rabu, 15 Desember 2010, sekitar pukul 01.30 WITA sekitar malam hari atau tepat di bagian pertama hari itu, di tempat keluarga Saksi Jendrik Tandioga di pintu belakang pisang, Dusun Angkona, Desa Tampinna, Kabupaten Luwu Timur. Sementara itu, Terdakwa melakukan pyrocrime dengan menuangkan 
bahan bakar ke tempat tidur atau tempat tidur yang ditutup dengan kelambu. Sestika Santika. Bahwa kegiatan Tergugat menelepon dan mengirim pesan melalui SMS tergantung pada keterangan pengamat dan keterangan penggugat sekitar 1 (satu) minggu sebelum terjadinya kebakaran hutan secara tidak sah. Oleh karena itu, jika Anda melihat rentang waktu yang ada, Terdakwa benar-benar memiliki pilihan untuk membatalkan rencananya untuk membakar kejahatanterkait, tetapi Terdakwa melanjutkan pembakaran ilegalnya.

3. Merampas Nyawa Orang Lain

Komponen mengambil nyawa orang lain dalam KUHP adalah perbuatan salah yang tidak dicirikan dengan demonstrasi, tetapi hanya menggarisbawahi akibat dari kegiatannya, khususnya meninggalnya jiwa seseorang dan "hilang" muncul karena demonstrasi itu, tidak harus terjadi segera, namun bisa muncul kemudian dalam semangat atau kehidupan. seseorang harus melakukan demonstrasi yang dapat menimbulkan korban jiwa atau korban jiwa. Kegiatan tersebut dapat terdiri dari, antara lain:
a. Menembak dengan senjata
b. Memukul dengan besi
c. Menusuk atau memotong dengan senjata tajam
d. Mencekik lehernya
e. Memberikan racun
f. Tenggelam

Bahwa pada hari Rabu tanggal 15 Desember 2010, sekitar pukul 01.30 WITA sekitar waktu petang atau dini hari, di tempat orang-orang Saksi Jendrik Tandioga di pintu belakang pisang, Dusun Angkona, Desa Tampinna, Kabupaten Luwu Timur. Sementara itu, Terdakwa melakukan pyrocrime dengan menuangkan bahan bakar ke tempat tidur atau tempat tidur yang ditutup dengan kelambu. Sestika Santika.

Bahwa Tergugat telah menghubungi pemantau melalui telepon danSMS pada saat korban berada di Tana Toraja dan Tergugat memberitahukan kepada pemantau bahwa "kalau kamu tidak pulang, saya bunuh orang tuamu" dan penggugat pernah mengirimkan surat SMS ke pengamat mengatakan bahwa "Saya akan mengkonsumsi rumah Anda" . Selain itu, penggugat sengaja memasangkan korek api kepada pengamat karena termohon merasa sakit hati terhadap pengamat dengan alasan pengamat meminta pisah karena pemukulan yang biasa dilakukan oleh penggugat dan penggugat percaya bahwa orang tua pengamat konsisten mencampuri urusankeluarga responden.

Bahwa karena kegiatan responden, Christina Tandioga mengalami konsumsi asli dan akhirnya meninggal dunia sebagaimana tertuang dalam Visum et Repertum Nomor 031/VER/RSUD/ILG/LT/I/2016, tanggal 27 Januari 2016 yang diberikan oleh RSUD I Lagaligo yang berkomitmen dan disahkan setelah bersumpah untuk mengatakan yang sebenarnya dari kantoroleh dr. Sikrong, Sp.B sebagai dokter spesialis di RSUD I Lagaligo

Bahwa dari seluruh rangkaian dan uraian pertimbangan, maka denan demikian seluruh unsur Pasal 340 KUHP dalam Dakwaan Kesatu Primair telah terbukti. Kegiatan Terdakwa diatur dan dipidana dengan pidana sebagaimana dimaksud dalam Pasal 80 Ayat (2) UU No. 23 Tahun 2002 tentang Perlindungan Anak, yang komponenkomponennya adalah sebagai berikut :

1. Semua orang

Komponen setiap individu adalah untuk mengetahui siapa pelaku tindak pidana yang berlaku sebagai subjek yang sah telah melakukan kesalahan dan dapat sadar tergantung pada kondisi dan kemampuan intelektualnya (geestelijke vermogens) yang dalam sila hukum pidana diuraikan sebagai negara yang sadar.

Bahwa tergantung pada kenyataan hukum yang dihubungkan dengan keterangan saksi-saksi yang diidentikkan satu sama lain dengan keterangan- keterangan termohon, maka fakta-fakta tersebut menegaskan bahwa yang berperkara Alwi Rongkeng Alias Awi dalam keadaan sehat jasmani dan rohani, sehingga ia dapat dianggap bertanggung jawab sebagaimana ditunjukkan oleh undang-undang olehnya "setiap komponen" telah puas.

2. Menyerahkan Kekejaman, Kekerasan atau Ancaman Kekerasan,atau Penganiayaan Anak

Bahwa apabila diidentikkan dengan kenyataan yang sah, ternyata pada hari Rabu tanggal 15 Desember 2010, sekitar pukul 01.30 WITA sekitar malam atau dini hari, di tempat orang-orang Saksi Jendrik Tandioga di jalan belakang pisang, Dusun Angkona, Desa Tampinna, Kabupaten Luwu Timur. Sementara itu Terdakwa melakukan tindak pidana kebakaran dengan cara menuangkan gas ke tempat tidur atau tempat tidur yang ditutup dengan kelambu, sudah Terdakwa menuangkan gas ke dalam kaleng dan sekitar itu, saksi Jenderal Tandioga sedang tertidur, namun Terdakwa tidak menyadari bahwa ada pengamat Cristina Tandioga dan pengamat. Sestika Santika. Kemudian dalam pemeriksaan pendahuluan diketahui bahwa pada saat pembakaran, saksi Sestika Santika masih duduk di bangku kelas VI SD (sesuai dengan akta kelahiran nomor 7324.AL2006.006632 pada saat kejadian, dia berumur 12 tahun). umur).

Bahwa karena kegiatan Penggugat, Saksi Sestika Santika mengalami konsumsi asli sebagaimana tertuang dalam Visum Et Repertum Nomor 030/VER/RSUD/ILG/Lt/I/2006, tanggal 27 Januari 2016 untuk kepentingan 
Anak Sestika Santika yang diberikan oleh Daerah Rumah Sakit Umum Daerah I Lagaligo yang dibuat dan disahkan berdasarkan surat perjanjian oleh dr. Sikrong. Sp.B sebagai dokter spesialis di RSUD I Lagaligo.

3. Unsur Yang Mengakibatkan Luka Berat

Komponen-komponen yang menyebabkan kerugian yang sejati diaturdalam Pasal 90 KUHP, khususnya:

a. Jatuh lemah atau mengalami masalah fisik yang tidak memberikan keinginan untuk sembuh apa pun atau yang merupakan risiko manusia.

b. Tidak dapat terus menyelesaikan kewajiban posisi atau mengejarpekerjaan.

c. Hilangnya salah satu fakultas.

d. Punya ketidakmampuan asli.

e. Menderita kehilangan gerak.

f. Gangguan daya pikir selama lebih dari sebulan.

g. Aborsi atau matinya perut wanita.

Bahwa jika mengacu pada kenyataan hukum di atas, maka sesuai dengan Unsur Pasal 90 KUHP dimana kegiatan penggugat terhadap pemantau Sestika Santika mengakibatkan kekurangan salah satu dari lima deteksi. Selain itu, apa yang tersirat dari lima deteksi itu terdiri dari penglihatan atau mata, penciuman atau hidung, rasa atau sensasi, kontak ataukulit dan pendengaran atau telinga.

Bahwa kumpulan saksi Sestika Santika telah kehilangan pekerjaan pengembangan atau membutuhkan adaptasi, terutama kulit daerah lengan bawah kiri dan kanan berwarna kemerahan dalam naungan, ada tambahan gelembung berisi cairan dan beberapa daerah luka putih muncul. Sehingga membuat bagian tubuh, terutama bagian yang terluka, mengeras, menebal dan ternyata mengeras.

Bahwa dari keseluruhan rangkaian gambaran renungan komponen- komponen di atas, maka secara konsekuen setiap komponen Pasal 80 Ayat (2) UU No. 23 Tahun 2002 tentang Perlindungan Anak telah dipuaskanterhadap kegiatan termohon. Bahwa Dakwaan Pratama Pertama adalah Pasal 340 KUHP danPratama Kedua adalah Pasal 80 Ayat (2) UU No. 23 Tahun 2002 tentang Perlindungan Anak telah terpenuhi. Bahwa Termohon dinyatakan bersalah secara sah dan meyakinkan karena telah melakukan perbuatan salah "Pembunuhan yang Direncanakan" dan "Penganiayaan Anak yang Menyebabkan Luka Berat".

\section{Pertimbangan Hakim dalam Menangani Tindak Pidana PembunuhanBerencana dan Penganiayaan Terhadap Anak Yang Mengakibatkan LukaBerat dalam Studi Putusan No. 36/Pid.B/2016/PN.MLL}

Perenungan hakim adalah pertentangan atau alasan yang digunakan oleh yang diputuskan sebagai perenungan sah yang menyusun premis sebelum memilih suatu perkara. Renungan para juri dibagi menjadi 2 (dua) bagian, yaitu:

1. Pertimbangan Yuridis

Perenungan hakim yang bergantung pada kenyataan yuridis yang terungkap dalam pendahuluan dan oleh undang-undang ditetapkan sebagai yang harus diingat untuk pilihan, misalnya dakwaan penyidik umum, keterangan penggugat, artikulasi saksi, pembuktian dan pasal-pasal dalam pedoman hukum pidana. Perenungan yuridis terhadap delik yang didakwakan juga harus sesuai dengan sudut hipotetis, perspektif doktrinal, undangundang dan situasi kasus yang sedang ditangani, maka, pada saat itu, pencetusnya tidak akan benar-benar diselesaikan. Setelah masuknyakomponen-komponen tersebut, praktis berbicara tentang pilihan hakim,maka pada saat itulah hal-hal yang dapat meringankan atau memberatkan responden dipikirkan. Hal-hal yang meresahkan, misalnya, terdakwa telah didakwa sebelumnya, akibat posisinya dan penggunaan spanduk publik. ${ }^{9}$

2. Pertimbangan Non-Yuridis

Perenungan non yuridis dapat dilihat dari dasar penggugat, kondisi termohon dan agama penggugat. ${ }^{10}$ Undang-undang Nomor 48 Tahun 2009 tentang Kekuasaan Kehakiman Pasal 5 ayat (1) mengatur bahwa hakim wajib menyelidiki, mengikuti, dan memahami sifat-sifat legitimasi dan rasakeadilan yang hidup di arena publik. Alasan pengaturan ini adalah bahwa pilihan masing-masing hakim sesuai dengan pengaturan yang sah dan rasa keadilan bagi daerah setempat.

Sedangkan untuk keadaan ini Majelis Hakim sependapat dengan tuntutan pidana dari Penuntut Umum yang menyatakan, Terdakwa terbukti telah melakukan "Pembunuhan Berencana" dan "Penganiayaan Anak Menyebabkan Luka Berat" sebagaimana diungkapkan dalam dakwaan yang dikumpulkan secara agregat, namun lamanya hukuman yang diajukan oleh Penuntut Umum, khususnya untuk waktu yang cukup lama di penjara, seperti yang ditunjukkan oleh Majelis, akan dipertimbangkan dalam pilihan. Hal ini dengan alasan bahwa dengan memeriksa hasil perbuatan Terdakwa yang menyebabkan meninggalnya Christina Tandioga dan Sestika Santika benar-benar dirugikan.

\footnotetext{
${ }^{9}$ Adami Chazawi, Kejahata terhadap Tubuh \& Nyawa, Jakarta, PT .Raja Grafindo,hlm 73.

${ }^{10}$ Rusli Muhammad, Hukum Acara Pidana Konteporer, Bandung: PT Citra Aditya Bakti,2007,hlm 212.
} 
Sebagaimana dikemukakan bahwa ada beberapa pertimbangan hakim dalam menjatuhkan putusan terhadap perkara yang berperkara dengan Alwi Rongkeng tersebut, berikut akan diuraikan pertimbangan dari pejabat yang ditunjuk:

1. Majelis dianggap sebagai tuntutan pokok yang esensial untuk melakukan perbuatan salah sebagaimana disinggung dalam Pasal 340 KUHP. Dengan Elemen Berikut:

a. Unsur Barang Siapa

Komponen siapa adalah komponen siapa pun untuk mengetahui siapa pelaku dari suatu demonstrasi kriminal sebagai subjek yangsah yang telah melakukan kesalahan dan dapat cakap tergantung pada kondisi dan kemampuan intelektualnya (geestelijke vemogens) yang dalam ajaran hukum pidana diuraikan sebagai berada dalam keadaan sadar. Dalam dakwaan yang didokumentasikan penyidik, Alwi Rongkeng adalah orang yang dibawa ke penyidikan. Sepanjang garis ini, komponen siapa pun telah dipenuhi.

b. Dengan Sengaja Dan Dengan Rencana Terlebih Dahulu Komponen sengaja dan mendahului waktu adalah suatu keadaan atau keadaan pelakunya yang sejauh menyelesaikan kegiatannya memerlukan waktu atau penundaan untuk mula-mulamempertimbangkan dengan lancar dalam menetapkan pilihanuntuk memusnahkan jiwanya dan pelaksanaannya merupakan suatu solidaritas. Melihat kenyataan yang terungkap, kegiatan Terdakwa yang menelepon dan mengirim pesan melalui SMSbergantung pada keterangan pengamat dan keterangan penggugat sekitar 1 (satu) minggu sebelum peristiwa tindak pidana kebakaran. Jadi, jika Anda melihat rentang waktu, Terdakwamemiliki pilihan untuk membatalkan pengaturannya untukmenyalakan api, tetapi Tergugat terus menghabiskannya. Sepanjang garis ini, komponen yang disengaja dan diatur sebelumnya telah terpenuhi.

c. Unsur Merampas Nyawa Orang Lain

Komponen mengambil nyawa orang lain dalam KUHP adalah perbuatan salah yang tidak dicirikan dengan demonstrasi, namun hanya menonjolkan hasil dari kegiatannya, khususnya berangkatnya jiwa seseorang dan "hilang" muncul karena demonstrasi itu, itu tidak harus terjadi segera, namun bisa muncul kemudian dalam semangat atau kehidupan. seseorang harus melakukan demonstrasi yang dapat menimbulkan korban jiwa atau korban jiwa. Kegiatan tersebut dapat terdiri dari, antara lain :

1) Menembak dengan senjata

2) Memukul dengan besi

3) Melukai atau memotong dengan senjata tajam

4) Mencekik lehernya

5) Pemberian zat beracun

6) mencekik

Maka unsur merampas nyawa orang lain telah terpenuhi.

2. Majelis Hakim berpendapat bahwa tuntutan pokok selanjutnya adalah melakukan perbuatan salah sebagaimana dimaksud dalam Pasal 80 Ayat Undang-Undang Nomor 23 Tahun 2002 tentang Perlindungan Anak. Dengan komponen yang menyertainya:

a. Setiap Orang

Hakim mempertimbangkan bahwa mengenai unsur setiap orang telah dipertimbangkan, maka majelis mengambil alih pertimbangan bahwa unsur setiap orang tersebut telah terpenuhi.

b. Melakukan Kekejaman, Kekerasan Atau Ancaman Kekerasan, Atau Penganiayaan Terhadap Anak

Pada pemeriksaan pendahuluan diketahui bahwa pada saat pembakaran, saksi Sestika Santika masih duduk di bangku kelas VI SD (berdasarkan akta kelahiran nomor 7324.AL2006.006632 pada saat kejadian, ia berusia 12 tahun). usia). Bahwa karena kegiatan Termohon, saksi Sestika Santika mengalami konsumsi asli sebagaimana tertuang dalam Visum Et Repertum Nomor 030/VER/RSUD/ILG/Lt/I/2006, tanggal 27 Januari 2016 untuk kepentingan Anak Sestika Santika yang diberikan oleh Pemerintah Daerah. Rumah Sakit Umum Daerah I Lagaligo yangdibuat dan disahkan berdasarkan surat perjanjian oleh dr. Sikrong.Sp.B sebagai dokter spesialis di RSUD I Lagaligo.

c. Unsur Yang Mengakibatkan Luka Berat

Bahwa kumpulan saksi Sestika Santika telah kehilangan pekerjaan pengembangan atau membutuhkan adaptasi, terutama kulit daerah lengan bawah kiri dan kanan berwarna kemerahan, juga terdapat gelembung-gelembung berisi cairan dan beberapa daerah luka berwarna putih muncul. Sehingga membuat bagian tubuh, terutama bagian yang terluka, mengeras, menebal danternyata menjadi kaku.

3. Dipertimbangkan Hal-Hal Yang Memberatkan

a. Terdakwa telah di pengadilan beberapa kali

b. Kegiatan terdakawa tidak peka

c. Kegiatan terdakwa mengabaikan kebebasan bersama

d. Terdakawa setelah melakukan demonstrasi kriminalnya melarikan diri untuk menghindari tindakan resmi 
Pajriniah Dwi Napanti dan Raden Yulia Kartika, Analisis Yuridis terhadap Tindak Pidana Pembunuhan Berencana Dan Penganiayaan terhadap Anak yang Mengakibatkan Luka Berat (Studi Putusan No. 36/Pid.B/2016/PN.MLL)

terhadapnya.

Hakim dalam menjatuhkan pidana kurungan keberadaan sehari-hari dengan mengabaikan syarat atau syarat yang meringankan bagi termohon seharusnya mempunyai pilihan untuk memberikan gambaran yang jelas bahwa penggugat ALWI RONGKENG dengan nama palsu AWI adalah demonstrasi yang mengandung unsur kebiadaban, misalnya BARBAR Suku dimana tanpa kebajikan dan kesesatan mengkonsumsi Christina Tandioga sampai mati dan Sestika Santika mengalami konsumsi yang terjadi dalam bentuk penyerahan dalam kapasitas kulitnya sehingga kegiatan Terdakwa dapat digolongkan sebagai makhluk alam dimana dalam mempertahankan kehidupan seseorang harus membunuh atau membuang saingan yang dipandang sebagai hambatan untuk tujuan.

Demikian investigasi pencipta atas pertimbangan hakim dalam menghukum termohon yang melakukan kesalahan pembunuhan berencana dan penyalahgunaan anak yang terjadi pada luka-luka yang nyata.

\section{SIMPULAN}

1. Pengunaan hukum terhadap perbuatan pidana pembunuhan berencana dan penyalahgunaan anak yang mengakibatkan luka yang nyata, Termohon dituduh melakukan perbuatan salah pembunuhan berencana yang mengakibatkan meninggalnya korban Christina Tandioga dan penyalahgunaan anak yang mengakibatkan cedera serius pada Sestika Santika. Seperti, dakwaan pokok dari Jaksa Penuntut Umum Pasal 340 KUHP dan dakwaan kedua dari Jaksa Penuntut Umum, Pasal 80 Ayat (2) Undang-Undang Nomor 23 Tahun 2002.

2. Majelis memikirkan pokok pokok tuntutan dan pokok tuntutan pokokkedua, khususnya bahwa alasan pejabat yang ditunjuk itu berpikir monumental kalimat itu adalah bahwa setiap pasal yang dituntut telah dipenuhi dan mengingat hal-hal yang menyangkut tergugat, maka pada saatitu hukuman yang dijatuhkan kepada penggugat dianggap telah memenuhirasa keadilan.

\section{DAFTAR PUSTKA}

\section{Buku}

Andi Hamzah, Bunga Rampai Hukum Pidana dan Acara Pidana, Jakarta : GhaliaIndonesia, 2001.

Bambang, Waluyo, Pidana dan Pemidanaan. Jakarta : Sinar Grafika, 2008. Lamintang P. A. F dan Theo Lamintang, Kejahatan Terhadap Nyawa, Tubuh danKesehatan, Jakarta : Sinar Grafika, 2010.

Moeljatno, Asas-Asas Hukum Pidana, Jakarta : Rineka Cipta, 2002. Poerdarminto, Kamus Umum Bahasa Indonesia, Jakarta : Balai Pustaka, 2003.

R. Soesilo, Kitab Undang-Undang Hukum Pidana, Bandung : Politeia, 1996.

R. Soesilo, Kitab Undang-Undang Hukum Pidana Serta Komentar-komentarnyaLengkap Pasal Demi Pasal, Bandung : Politeia, 1980.

Wahyu Adnan, Kejahatan Terhadap Tubuh dan Nyawa, Bandung : Gunung Aksara,2007.

\section{Jurnal}

Ewis Meywan Batas. "Tindak Pembunuhan Berencana Menurut Pasal 340 KitabUndang-Undang Hukum Pidana”, Lex Crimen Vol. V, (Februari 2016) : 2 .

Firman Umar, Irda. "Penanganan Kasus Anak Korban Kejahatan Penganiayaan".

Jurnal Supremasi Vol. XII, (April 2017) : 1.

Veronica Pratiwi, Nursiti. "Tindak Pidana Pembunuhan Berencana Yang Dilakukan Secara Bersama-Sama”. Jurnal Ilmiah Mahasiswa. Vol. 2, (Novemeber 2018).

\section{Undang-Undang}

Undang-Undang No. 1 Tahun 1946 tentang Kitab Undang-Undang Hukum Pidana(KUHP)

Undang-Undang No. 23 Tahun 2002 Tnetang Perlindungan Anak

\section{Putusan}

Putusan No. 36/Pid.B/2016/PN.MLL 